\title{
ETHzürich
}

\section{Integrity check of structural softwood glue lines: correspondence between delamination and block shear tests}

\author{
Journal Article \\ Author(s): \\ Steiger, René; Arnold, Martin; Risi, Walter \\ Publication date: \\ 2014-11 \\ Permanent link: \\ https://doi.org/10.3929/ethz-b-000091960
}

Rights / license:

In Copyright - Non-Commercial Use Permitted

Originally published in:

European Journal of Wood and Wood Products 72(6), https://doi.org/10.1007/s00107-014-0838-0 


\title{
Integrity check of structural softwood glue lines: correspondence between delamination and block shear tests
}

\author{
René Steiger • Martin Arnold · Walter Risi
}

Received: 13 March 2014/Published online: 28 September 2014

(c) Springer-Verlag Berlin Heidelberg 2014

\begin{abstract}
In factory production control (FPC) of gluedlaminated timber the integrity of glue lines according to product standards has to be checked by carrying out either delamination or block shear tests. The chosen test method should provide reliable and reproducible results, and from a practical point of view should be as cheap and easy to perform as possible. An extensive experimental study aiming at systematically comparing the outcomes of delamination and shear tests on structural softwood glue lines using different wood species and adhesives was carried out. In the delamination tests, the length of open glue lines was assessed after subjecting the test specimens to vacuum- and pressure-soaking and to subsequent drying. In the block shear tests, the shear strength and wood failure percentage were determined. Only if the benchmark values in the product standards were met or exceeded, the respective specimen passed the test and the glue lines were regarded as sound. As a main overall result it turned out that the outcomes of both test methods generally agree well, but will not necessarily lead to the same pass/fail conclusion in any case. Therefore, for FPC the choice of their application should be defined more specifically.
\end{abstract}

\section{Abbreviations}

ASTM American Society for Testing and Materials

\section{R. Steiger $(\bowtie)$}

Structural Engineering Research Laboratory, Empa-Swiss Federal Laboratories for Materials Science and Technology, Ueberlandstrasse 129, 8600 Dübendorf, Switzerland

e-mail: rene.steiger@empa.ch

M. Arnold · W. Risi

Applied Wood Materials, Empa-Swiss Federal Laboratories for Materials Science and Technology, Ueberlandstrasse 129, 8600 Dübendorf, Switzerland
CEN European Committee for Standardization

DIB Percentage of intact glue line length after the delamination test (aggregated result of delamination tests, averaged over methods A and B)

EN European standard

EPI Emulsion Polymer Isocyanate

FPC Factory production control

Glulam Glued-laminated timber

MC Moisture content

MUF Melamine-Urea-Formaldehyde

PUR Polyurethane

PRF Phenol-Resorcinol-Formaldehyde

RH Relative humidity (of air)

SC Service class

SFV Shear strength (aggregated result of block shear tests, averaged over 3 pre-conditioning treatments)

SWF Wood failure percentage (aggregated result of block shear tests, averaged over 3 preconditioning treatments)

UF Urea-Formaldehyde

WFP Wood failure percentage (in block shear tests)

\section{Introduction}

Due to natural limits in size of sawn wood, timber structural elements in many cases consist of glued members like glued-laminated (glulam) columns and beams or glued solid timber. The major requirement for structural elements is to guarantee their reliability in use in terms of strength, stiffness and durability. Besides tensile strength and stiffness of the finger jointed boards (lamellas), the quality of glue lines between the lamellas (face gluing) decisively 
impacts the performance of glulam. Factory production control (FPC) therefore is an important tool in guaranteeing the required performance. FPC usually follows strict rules and procedures laid down in standards. In this study, a set of European standards consisting of EN 386 (European Committee for Standardization CEN 2001a), EN 391 (European Committee for Standardization CEN 2001b) and EN 392 (European Committee for Standardization CEN 1995) was used. These standards were valid at the time of planning and carrying out the experiments. In the meantime, the mentioned standards became part of the current European product standard EN 14080 (European Committee for Standardization CEN 2013), which prescribes the requirements in glued laminated and glued solid timber. According to the provisions, FPC of glued members requires checking the integrity of the glue lines by either delamination or block shear tests.

Delamination tests assess the integrity of glue lines by exposing them to different climatic conditions and, hence, are regularly used in the course of developing and improving structural adhesives as well as in FPC of glued timber products intended to be used in load-bearing structures. The delamination test shows in terms of "Pass/ Fail" whether the adhesive bond can withstand climatic stresses. The procedure is to vacuum-pressure saturate cross-sectional test pieces in different cycles with water and to dry them rapidly so that the resulting drying stresses will produce either cracks in the wood, cohesion failure in the glue line or adhesion failure in the wood-adhesive interface. The latter types of failures together with wood failure occurring within the first one or two layers of cells beyond the glue line are evaluated as delamination (European Committee for Standardization CEN 2013). The amount of delamination is influenced by the severity of the applied climatic cycles (soaking and drying of the specimens). That is why standards used in FPC of glulam (e.g. EN 386 or EN 14080) define different delamination methods being suitable for different types of adhesives or different climatic exposure conditions of the structural members, respectively. The validity of the delamination test method is not based on a differentiated evaluation of the variety of climatic situations a glue line may be exposed to during its service life, but rather on long-term practical experience that the glue line will keep its integrity, provided the delamination test has been passed successfully (Aicher and Reinhardt 2007).

Depending on the local climate the glulam structural element will be exposed to when in use, the standard EN 391 (European Committee for Standardization CEN 2001b) (or Annex C of EN 14080 (European Committee for Standardization CEN 2013)) provides three different delamination test methods (A, B, C) to assess the glue line integrity (Table 1). Methods A and B can be applied to structural products for use in all service classes (SC), method C is limited to SC 1 and 2. SC 1 is characterized by a wood moisture content (MC) corresponding to a temperature of $20^{\circ} \mathrm{C}$ and the relative humidity $(\mathrm{RH})$ of the surrounding air exceeding $65 \%$ for only a few weeks per year, SC 2 with the MC in the wood corresponding to a temperature of $20{ }^{\circ} \mathrm{C}$ and $\mathrm{RH}$ of the surrounding air exceeding $85 \%$ for only a few weeks per year and SC 3 is characterized by climatic conditions leading to higher MC than in SC 2 (European Committee for Standardization CEN 2004).

By means of block shear tests on prismatic specimens with a pre-defined cross-sectional area (e.g. $t \times b=(40-50) \mathrm{mm} \times(40-50) \mathrm{mm}$ according to the European standard EN 392 (European Committee for Standardization CEN 1995) or 1.75 inch $\times 2$ inch according to the American standard ASTM D 905-03 (American Society for Testing and Materials ASTM 2003) respectively), the shear strength and the wood failure percentage (WFP) of glue lines can be assessed. The shear strength depends on the strength of the adherend materials wood and adhesive, on the stress distribution within the glue line and on the ability of the adhesive to transfer the acting stress into the glue line and thus from one adherend surface to the other. The WFP indicates which of the materials (wood, adhesive) is weaker in terms of the ratio of areas which failed within the glue line (cohesive failure) or in the wood-adhesive interface (adhesion failure), and those failed in the wood itself. Several studies (e.g. Bodig and Jayne 1993; Coker and Coleman 1935; Radcliffe and Suddarth 1955; Steiger et al. 2010) have shown that results of block shear tests are influenced by the type of test equipment and by the constructional detailing of the support as well as by the way the specimens are set and loaded in the test apparatus. According to EN 392 (or Annex D of EN 14080) standard block shear tests can be performed to assess glue line integrity of glulam structural elements in SC 1 and 2.

Both block shear and delamination tests have been applied frequently in research as well as in FPC. Current practice of glulam FPC in Europe following the rules in EN 386 assumes a positive correlation of delamination tests and short-term block shear tests (Aicher and Reinhardt 2007; Zeppenfeld and Grunwald 2005) at least for SC 1 and 2. Hence, state-of-the-art regulations for FPC of glulam base on the assumption that glue line integrity can be proven if the standardized limits in either delamination tests or block shear tests are passed by a sample of specimens. The respective benchmark values are presented in Tables 2 and 3.

Some studies indicate that the results of delamination tests are in line with those from block shear tests, while others show contradicting results between the two test 
Table 1 EN 391 methods for delamination testing of glue lines

\begin{tabular}{|c|c|c|c|c|c|}
\hline \multirow[t]{2}{*}{ Treatment } & & & \multicolumn{3}{|l|}{ Method } \\
\hline & & & A & $\mathrm{B}$ & $\mathrm{C}$ \\
\hline \multirow{7}{*}{$\begin{array}{l}\text { Vacuum- and pressure-soaking } \\
\text { cycles in water }\end{array}$} & \multicolumn{2}{|c|}{ Water temperature $\left[{ }^{\circ} \mathrm{C}\right]$} & $10-20$ & $10-20$ & $10-20$ \\
\hline & \multirow[t]{2}{*}{ Vacuum } & Absolute pressure $[\mathrm{kPa}]$ & $15-30$ & $15-30$ & $15-30$ \\
\hline & & Duration [min] & 5 & 30 & 30 \\
\hline & \multirow[t]{2}{*}{ Pressure } & Absolute pressure $[\mathrm{kPa}]$ & $600-700$ & $600-700$ & $600-700$ \\
\hline & & Duration [min] & 60 & 120 & 120 \\
\hline & \multicolumn{2}{|c|}{ Number of cycles } & 2 & 1 & 2 \\
\hline & \multicolumn{2}{|c|}{ Total duration [min] } & 130 & 150 & 300 \\
\hline \multirow[t]{5}{*}{ Drying cycles } & \multicolumn{2}{|c|}{ Temperature $\left[{ }^{\circ} \mathrm{C}\right]$} & $65 \pm 5$ & $70 \pm 5$ & $27.5 \pm 2.5$ \\
\hline & \multicolumn{2}{|c|}{ Relative humidity [\%] } & $<15$ & $9 \pm 1$ & $30 \pm 5$ \\
\hline & \multicolumn{2}{|c|}{ Velocity of circulating air $[\mathrm{m} / \mathrm{s}]$} & $2.5 \pm 0.5$ & $2.5 \pm 0.5$ & $2.5 \pm 0.5$ \\
\hline & \multicolumn{2}{|c|}{ Duration [h] } & $21-22$ & $10-15$ & 90 \\
\hline & \multicolumn{2}{|c|}{ Termination criterion } & a & $\mathrm{b}$ & a \\
\hline \multicolumn{6}{|l|}{ General parameters } \\
\hline \multicolumn{3}{|l|}{ Number of initial cycles } & 2 & 1 & 1 \\
\hline \multicolumn{3}{|c|}{ Number of extra cycles (repetitions) ${ }^{c}$} & 1 & 1 & 0 \\
\hline \multicolumn{3}{|l|}{ Overall duration $[\mathrm{h}]^{\mathrm{d}}$} & $48(72)$ & $12.5-17.5(25-35)$ & 95 \\
\hline
\end{tabular}

a Drying cycle passed

b The actual drying is controlled by the mass of the specimen. The drying cycle ends when the mass of the specimen has returned to within $100-110 \%$ of the original mass

c An extra test cycle only has to be carried out, if the total delamination percentage according to Eq. (1) is larger than the prescribed maximum value

d The value in brackets indicates the duration for cases with extra cycles

Table 2 EN 386 benchmarks for delamination tests

\begin{tabular}{llll}
\hline Method & \multicolumn{3}{l}{$\begin{array}{l}\text { Maximum total delamination percentage (Eq. (1)) after } \\
\text { cycle number: }\end{array}$} \\
\cline { 2 - 4 } & 1 & 2 & 3 \\
\hline A & - & 5 & 10 \\
B & 4 & 8 & - \\
C & 10 & - & - \\
\hline
\end{tabular}

For all delamination methods the maximum delamination percentage (Eq. 2) shall be less than or equal to $40 \%$ (In the current standard EN 14080 this value was reduced to $30 \%$ )

methods. In Norway, Raknes (Raknes 1983, 1997) carried out durability tests on several types of adhesives used for structural softwood (Norway spruce, Picea abies L.) bonding. Some of the specimens showed acceptable strength in block shear tests after 30 years of indoor and (protected as well as unprotected) outdoor exposure, but comparative specimens did not fulfil the delamination requirements of at that time relevant standard ASTM D 1101-59 (American Society for Testing and Materials ASTM 1959). Tests reported in Aicher and Reinhardt (2007) to derive delamination properties and shear strength of glued beech wood (Fagus sylvatica L.)
Table 3 Minimum required wood failure percentage related to shear strength according to EN 386

\begin{tabular}{lllllll}
\hline Parameter & Average values & \multicolumn{3}{l}{ Individual values } \\
\hline $\begin{array}{l}\text { Shear strength } f_{v} \\
{\left[\mathrm{~N} / \mathrm{mm}^{2}\right]}\end{array}$ & 6 & 8 & $f_{v} \geq 11$ & $4 \leq f_{v}<6$ & 6 & $f_{v} \geq 10$ \\
$\begin{array}{l}\text { Minimum wood } \\
\text { failure percentage }\end{array}$ & 90 & 72 & 45 & 100 & 74 & 20 \\
$\quad$ WFP [\%] & & & & & & \\
\hline
\end{tabular}

a For average values the minimum wood failure percentage $W F P_{a}$ is: 144-9 $f_{v, \mathrm{a}}$. For individual values the minimum wood failure percentage $W F P_{i}$ for shear strengths $f_{v, i} \geq 6 \mathrm{~N} / \mathrm{mm}^{2}$ is: $153.3-13.3 f_{v, i}$ Indexes a and i refer to average and individual values, respectively

laminations with red heartwood have shown partly contradicting results from both test methods, and the authors suggested to perform further research. Two recently published studies on the glueability of European beech wood (Fagus sylvatica $L$.) for load bearing timber structures (Schmidt et al. 2010) and on the influence of wood properties and bonding parameters on bond durability (Ohnesorge et al. 2010) again revealed that there was no clear link between the results from block shear and delamination tests. Hence, the authors of the latter study recommended delamination tests rather than block shear tests for FPC of structural beech wood bonding. 
These findings raise questions regarding the validity and correspondence of the two test methods. On the one hand, a test method should guarantee reliable and reproducible results not suffering from being influenced by the person who carries out the tests. On the other hand, from a practical point of view, the applied method should be as cheap and easy to perform as possible.

From a survey among five important Swiss glulam producers (A-E) regarding their raw material (wood species) and the adhesives for surface gluing of the lamellas mainly used in their glulam production it turned out that the producers mainly use Norway spruce (Picea abies $L$.) and silver fir (Abies alba Mill.) (>90\%) with lamella thicknesses between 25 and $43 \mathrm{~mm}$ for glulam members primarily part of structures exposed to SC 1 and 2 (European Committee for Standardization CEN 2004). Four producers also process European larch wood (Larix decidua Mill.) and Douglas fir (Pseudotsuga menziesii Mirb.) and one producer reported to occasionally produce glulam from Maritime pine (Pinus pinaster Ait.). The survey furthermore revealed that four producers mainly use Melamine-Urea-Formaldehyde (MUF) type adhesives and one producer applies a Polyurethane (PUR) product. Occasionally, adhesives of the types Urea-Formaldehyde (UF), Phenol-Resorcinol- Formaldehyde (PRF) and Emulsion Polymer Isocyanate (EPI) are used.

Therefore, the authors recently carried out a study with the aim to systematically compare the results of delamination and block shear tests and to assess the respective test's power in evaluating the integrity of structural glue lines in softwood glulam. The following questions were addressed in particular:
- Do the two test methods agree in assigning "Pass" or "Fail" to a specific specimen?

- Is there a correlation between the results of both test methods?

- How sensitive are the assessed test parameters?

- Do both methods agree in detecting single weak glue lines?

\section{Materials and methods}

\subsection{General test procedure}

The experimental plan was based on the results of the mentioned survey. The power of different test methods to assess the integrity of glue lines can only be evaluated if standardized test methods are used. Hence, it was decided to rely the study on the European standards EN 386 (European Committee for Standardization CEN 2001a), EN 391 (European Committee for Standardization CEN 2001b) and EN 392 (European Committee for Standardization CEN 1995). All tests were carried out by one single person.

\subsection{Test specimens}

Each producer supplied six end-matched prismatic glulam cross-sections for each test series consisting of different wood species and adhesives (Table 4). Four test pieces were $45 \mathrm{~mm}$ thick and served as raw material to cut two parallel block shear test bars (series 7-9: only one bar) with glue line dimensions of $45 \times 50 \mathrm{~mm}^{2}$, the length of the

Table 4 Overview of test series with the key parameters of the tested glulam material

\begin{tabular}{|c|c|c|c|c|c|c|c|}
\hline Series & Producer & $\begin{array}{l}\text { Wood } \\
\text { species }^{\text {a }}\end{array}$ & $\begin{array}{l}\text { Type of } \\
\text { adhesive }^{b}\end{array}$ & $\begin{array}{l}\text { Glulam cross-section } \\
\text { width } \mathrm{x} \text { height }(\mathrm{mm})\end{array}$ & $\begin{array}{l}\text { Lamella } \\
\text { thickness (mm) }\end{array}$ & $\begin{array}{l}\text { Number of } \\
\text { glue lines }\end{array}$ & $\begin{array}{l}\text { Number of bars } \\
\text { in block shear test }\end{array}$ \\
\hline 1 & B & S & MUF & $160 \times 440$ & 41 & 10 & 2 \\
\hline 2 & B & $\mathrm{L}$ & MUF & $100 \times 320$ & 30 & 10 & 2 \\
\hline 3 & $\mathrm{D}$ & $\mathrm{D}$ & MUF & $160 \times 250$ & 43 & 5 & 2 \\
\hline 4 & $\mathrm{D}$ & $\mathrm{L}$ & MUF & $160 \times 250$ & 32 & 7 & 2 \\
\hline 5 & $\mathrm{D}$ & $\mathrm{P}$ & MUF & $160 \times 250$ & 25 & 9 & 2 \\
\hline 6 & $\mathrm{E}$ & S & PUR & $180 \times 480$ & 41 & 11 & 2 \\
\hline 7 & A & S & EPI & $75 \times 400$ & 40 & 9 & 1 \\
\hline 8 & A & $\mathrm{L}$ & EPI & $75 \times 420$ & 38 & 10 & 1 \\
\hline 9 & A & $\mathrm{D}$ & EPI & $75 \times 331$ & 30 & 10 & 1 \\
\hline 10 & $\mathrm{C}$ & S & UF & $140 \times 365$ & 34 & 10 & 2 \\
\hline 11 & $\mathrm{C}$ & S & PRF & $140 \times 365$ & 34 & 10 & 2 \\
\hline 12 & $\mathrm{C}$ & S & MUF & $140 \times 365$ & 34 & 10 & 2 \\
\hline
\end{tabular}

a Wood species: D, Douglas fir (Pseudotsuga menziesii); L, European larch (Larix decidua); P, Maritime pine (Pinus pinaster); S, Norway spruce (Picea abies)

b Type of adhesives: MUF, Melamine-Urea-Formaldehyde; PUR, Polyurethane; EPI, Emulsion Polymer Isocyanate; UF, Urea-Formaldehyde; PRF, Phenol-Resorcinol-Formaldehyde 
bars corresponding to the height of the original glulam cross-section and the smaller dimension $(45 \mathrm{~mm})$ corresponding to the grain direction. The remaining two glulam test pieces were $75 \mathrm{~mm}$ thick and subjected as full-size specimens to delamination tests. The used test specimens thus resemble a 'typical' sample of industrially produced glulam, with limited comparability because of variable cross-sectional dimensions as well as variable thickness and number of lamellas.

\subsection{Delamination tests}

Being applicable to glulam in all service classes SC 1-3, glue line integrity was assessed according to EN 391 methods A and B (Table 1) and benchmarked according to EN 386 (Table 2). A further reason not to test according to method $\mathrm{C}$ was the long overall duration of $95 \mathrm{~h}$, which is not feasible for industrial application. The duration of test methods A and B is $48 \mathrm{~h}$ and 12.5-17.5 h, respectively.

Prior to testing, the specimens were stored for 8 weeks in standard climate $\left(20^{\circ} \mathrm{C} / 65 \% \mathrm{RH}\right)$. The procedure started with vacuum-soaking the specimens in water and afterwards pressure-soaking them. Then the specimens were dried in a special drying device (ULWA-E, Ulrich Lübbert Warenhandel $\mathrm{GmbH} \& \mathrm{Co}$. KG, Germany). The parameters of the different treatment steps depend on the actual delamination method (A, B) (Table 1).

After these cycles of vacuum- and pressure-soaking in water and subsequent drying, the amount and length of delamination in the above mentioned $75 \mathrm{~mm}$ thick glulam pieces were measured. Two different percentages of delamination as defined in EN 391 were calculated: (1) the total delamination of a single specimen $\left(D_{\text {tot }}\right)$, which expresses the proportion of the delamination length $\left(l_{\text {tot,delam }}\right)$ of all glue lines on both end-grain surfaces to the total length of all glue lines of a specimen ( $\left.l_{\text {tot,glue line }}\right)$ and (2) the maximum delamination $\left(D_{\max }\right)$ in any single glue line representing the proportion of the largest delamination length on both end-grain surfaces of a single glue line $\left(l_{\text {max,delam }}\right)$ to the total length on both end-grain surfaces of the same glue line ( $\left.2 l_{\text {glue line }}\right)$ :

$D_{\text {tot }}[\%]=100 \frac{l_{\text {tot,delam }}}{l_{\text {tot,glueline }}}$

and

$D_{\max }[\%]=100 \frac{l_{\text {max }, \text { delam }}}{2 l_{\text {glueline }}}$

Following the requirements in EN 391 (European Committee for Standardization CEN 2001b), glue line openings were considered as delamination if the openings resulted from (a) a cohesive crack within the adhesive layer, (b) a failure of the glue line exactly between the adhesive layer and the wood substrate (no fibres are left attached to the adhesive layer) or (c) a wood failure which was invariably within the first one or two layers of cells beyond the adhesive layer, in which the fracture path was not influenced by the grain angle and the growth-ring structure.

As benchmarks for delamination tests EN 386 limits the maximum total delamination percentage $D_{\text {tot }}$ to $5 \%$ after 2 cycles and $10 \%$ after 3 cycles when testing according to method A. Specimens tested according to method B may not suffer from total delamination percentages higher than $4 \%$ after 1 cycle and $8 \%$ after 2 cycles (Table 2). For both methods $\mathrm{A}$ and $\mathrm{B}$ the maximum delamination percentage $D_{\max }$ shall be less than or equal $40 \%$. (In the follow-up standard EN 14080 this value has been reduced to $30 \%$.)

\subsection{Block shear tests}

Block shear tests were carried out according to EN 392 (European Committee for Standardization CEN 1995) on cross-sectional bars with shear areas of $45 \times 50 \mathrm{~mm}^{2}$ (height $\times$ width).

In order to include different pre-test climatic exposures (similar to the concept of service classes) three subseries with a different pre-conditioning treatment were tested: Subseries 1-specimens were stored in standard climate 1 $\left(20{ }^{\circ} \mathrm{C} / 65 \% \mathrm{RH}\right)$, subseries 2 -specimens in standard climate $2\left(20{ }^{\circ} \mathrm{C} / 85 \% \mathrm{RH}\right)$ and subseries 3-specimens were exposed to a "stress climate" (vacuum- and pressuresoaking in water according to EN 391 method B followed by drying the specimens in standard climate $3,20{ }^{\circ} \mathrm{C} / 35 \%$ $\mathrm{RH})$.

The shear tests were carried out in force controlled regime on a universal testing machine (Zwick 1474, Zwick $\mathrm{GmbH} \&$ Co. KG, Germany) with a constant crosshead displacement rate such that failures occurred after $20 \mathrm{~s}$ at the earliest. In preceding studies it turned out that the results of shear tests may be influenced by the way the test specimen is supported and loaded in the test apparatus (Steiger et al. 2010). In the current tests the shear apparatus allowed a free lift-off of the specimen bars and the surface of the steel plate support was corrugated.The shear strength $f_{\mathrm{v}}\left[\mathrm{N} / \mathrm{mm}^{2}\right]$ was calculated from the failure load $F_{\mathrm{u}}[\mathrm{N}]$ and the sheared area $A\left[\mathrm{~mm}^{2}\right]$ as follows:

$f_{\mathrm{v}}\left[\mathrm{N} / \mathrm{mm}^{2}\right]=k \frac{F_{\mathrm{u}}[\mathrm{N}]}{A\left[\mathrm{~mm}^{2}\right]}$

with

$k=0.78+0.0044 t$.

The factor $k$ accounts for situations where the shape of the sheared area is not quadratic (European Committee for 
Table 5 Overview of results of 12 test series

\begin{tabular}{|c|c|c|c|c|c|c|c|c|c|c|}
\hline \multirow[t]{4}{*}{ Series } & \multirow[t]{4}{*}{ Wood species } & \multirow[t]{4}{*}{ Type of adhesive } & \multirow{2}{*}{\multicolumn{2}{|c|}{$\frac{\text { Delamination test }{ }^{\mathrm{a}}}{\text { Method }}$}} & \multicolumn{6}{|c|}{ Block shear test ${ }^{\mathrm{a}}$} \\
\hline & & & & & \multicolumn{6}{|c|}{ Average values of test pieces after pre-conditioning at } \\
\hline & & & \multirow{2}{*}{$\begin{array}{l}\mathrm{A} \\
D_{\mathrm{tot}}^{\mathrm{c}} \\
{[\%]}\end{array}$} & \multirow{2}{*}{$\begin{array}{l}\mathrm{B} \\
D_{\mathrm{tot}}^{\mathrm{c}} \\
{[\%]}\end{array}$} & \multicolumn{2}{|c|}{$1: 20^{\circ} \mathrm{C} / 65 \% \mathrm{RH}$} & \multicolumn{2}{|c|}{$2: 20^{\circ} \mathrm{C} / 85 \% \mathrm{RH}$} & \multicolumn{2}{|c|}{ 3: Stress climate } \\
\hline & & & & & $\begin{array}{l}f_{v, a} \\
{\left[\mathrm{~N} / \mathrm{mm}^{2}\right]}\end{array}$ & $\begin{array}{l}W F P_{a} \\
{[\%]}\end{array}$ & $\begin{array}{l}f_{v, a} \\
{\left[\mathrm{~N} / \mathrm{mm}^{2}\right]}\end{array}$ & $\begin{array}{l}W F P_{a} \\
{[\%]}\end{array}$ & $\begin{array}{l}f_{v, a} \\
{\left[\mathrm{~N} / \mathrm{mm}^{2}\right]}\end{array}$ & $\begin{array}{l}W F P_{a} \\
{[\%]}\end{array}$ \\
\hline 1 & $\mathrm{~S}$ & MUF & 4.5 & 3.5 & $9.9^{\mathrm{e}}$ & $\mathbf{8 3 . 8 ^ { \mathrm { e } }}$ & $8.3^{\mathrm{e}}$ & $89.5^{\mathrm{e}}$ & 10.8 & 95.0 \\
\hline 2 & $\mathrm{~L}$ & MUF & 3.1 & 0.9 & 11.8 & 91.8 & 10.1 & 93.8 & 11.6 & 95.3 \\
\hline 3 & $\mathrm{D}$ & MUF & 3.4 & 0.8 & 10.7 & 92.0 & 8.7 & 94.0 & 11.0 & 96.5 \\
\hline 4 & $\mathrm{~L}$ & MUF & 1.1 & 1.8 & 12.4 & 91.1 & 10.1 & 98.2 & 11.7 & 93.9 \\
\hline 5 & $\mathrm{P}$ & MUF & 0.1 & 1.5 & 13.6 & 95.6 & 11.2 & 97.5 & 11.8 & 96.1 \\
\hline 6 & $\mathrm{~S}$ & PUR & 1.3 & 1.0 & 10.1 & 97.1 & 9.0 & 92.1 & 11.4 & 94.8 \\
\hline 7 & $\mathrm{~S}$ & EPI & 8.8/10.7 & $5.3 / 9.3$ & 9.2 & 88.9 & 8.3 & 80.0 & 9.6 & 91.7 \\
\hline 8 & $\mathrm{~L}$ & EPI & $8.2 / 10.1^{\mathrm{d}}$ & $12.2^{\mathrm{d}}$ & $11.8^{\mathrm{e}}$ & $82.5^{\mathrm{e}}$ & $11.1^{\mathrm{e}}$ & $84.0^{\mathrm{e}}$ & 10.4 & 89.0 \\
\hline 9 & $\mathrm{D}$ & EPI & $8.7 / 10.1$ & $6.3 / 9.2$ & 9.8 & 72.0 & $9.5^{\mathrm{e}}$ & $75.6^{\mathrm{e}}$ & 10.6 & 88.9 \\
\hline 10 & $\mathrm{~S}$ & UF & 2.0 & 4.0 & $9.9^{\mathrm{e}}$ & $59.5^{\mathrm{e}}$ & $8.9^{\mathrm{e}}$ & $71.5^{\mathrm{e}}$ & 11.3 & 72.0 \\
\hline 11 & $\mathrm{~S}$ & PRF & 0.2 & 0.0 & $9.3^{\mathrm{e}}$ & $82.3^{\mathrm{e}}$ & 8.7 & 75.3 & 11.7 & 79.8 \\
\hline 12 & $\mathrm{~S}$ & MUF & $14.2^{\mathrm{d}}$ & $14.7^{\mathrm{d}}$ & $8.8^{f}$ & $58.3^{\mathrm{f}}$ & $9.2^{\mathrm{e}}$ & $82.5^{\mathrm{e}}$ & 11.2 & 68.8 \\
\hline \multicolumn{11}{|c|}{ Bold values indicate failure to meet requirements } \\
\hline \multicolumn{11}{|c|}{ Vacuum- and pressure-soaking in water according to EN 391 method $\mathrm{B}$, followed by drying at $20^{\circ} \mathrm{C} / 35 \% \mathrm{RH}$} \\
\hline \multicolumn{11}{|c|}{ c Second value indicates results of additional delamination test cycle due to high delamination in the first cycle } \\
\hline \multicolumn{11}{|c|}{ d Additionally exceeding maximum value for $D_{\max }$ of an individual glue line: $48.7 \%$ in series 8 and $42.9 \%$ in series 12} \\
\hline \multicolumn{11}{|c|}{ e Failure to meet requirements for individual glue lines $\left(f_{v, i}, W F P_{i}\right)$} \\
\hline$f$ & & ments for individual & ad average & & & & & & & \\
\hline
\end{tabular}

Standardization CEN 1995). In this case with $t=45 \mathrm{~mm}$ instead of $50 \mathrm{~mm}, k$ equals 0.978 .

The WFP was estimated after testing on both faces of the opened glue line with the help of a grid virtually laid over the sheared area and rounded to the nearest percentage figure divisible by 5 . Both shear strength and WFP were finally compared to the benchmarks given in the performance standard EN 386, indicating minimum wood failure percentages depending on the shear strength for both average values per test piece $\left(f_{v}, a, W F P_{a}\right)$ and individual glue lines $\left(f_{v, i}, W F P_{i}\right)$, respectively (Table 3$)$. According to the EN 386 requirements, the shear strength $f_{\mathrm{v}}$ should reach a value of at least $6 \mathrm{~N} / \mathrm{mm}^{2}$, with a minimum WFP of $90 \%$ for average values and $100 \%$ for individual values. For softwoods, individual values down to $f_{\mathrm{v}}=4 \mathrm{~N} / \mathrm{mm}^{2}$ are acceptable if the WFP is $100 \%$.

\subsection{Data analysis}

The initial analysis of the primary test data was based on the "Pass/Fail" evaluation according to the standards. Additionally, to analyse general trends and relationships in the data of the different test series, three 'aggregate' measures of glue line integrity were calculated according to formulas 5-7, namely the percentage of intact glue line length after the delamination test $(D I B)$, the shear strength $(S F V)$ and the wood failure percentage after the block shear test $(S W F)$ :

$D I B[\%]=100-\frac{\left(D_{\mathrm{tot}, \mathrm{A}}+D_{\mathrm{tot}, \mathrm{B}}\right)}{2}$

where subscripts $\mathrm{A}$ and $\mathrm{B}$ refer to delamination methods $\mathrm{A}$ and $\mathrm{B}$ (see Table 1), respectively.

$S F V\left[\mathrm{~N} / \mathrm{mm}^{2}\right]=\frac{f_{v, 1}+f_{v, 2}+f_{v, 3}}{3}$

$S W F[\%]=\frac{W F P_{1}+W F P_{2}+W F P_{3}}{3}$

where subscripts 1-3 refer to pre-conditioning treatments 1-3 (see Table 5), respectively.

For the above calculations, the following rules were defined:

- In order to get a numerical representation of the extent of delamination similar to wood failure percentage $(W F P$ ) in block shear tests (a higher value means a better result), a new parameter called 'intact glue lines' was calculated as $100-D_{\text {tot }}$, describing the not-delaminated percentage of glue lines. The new parameter has 


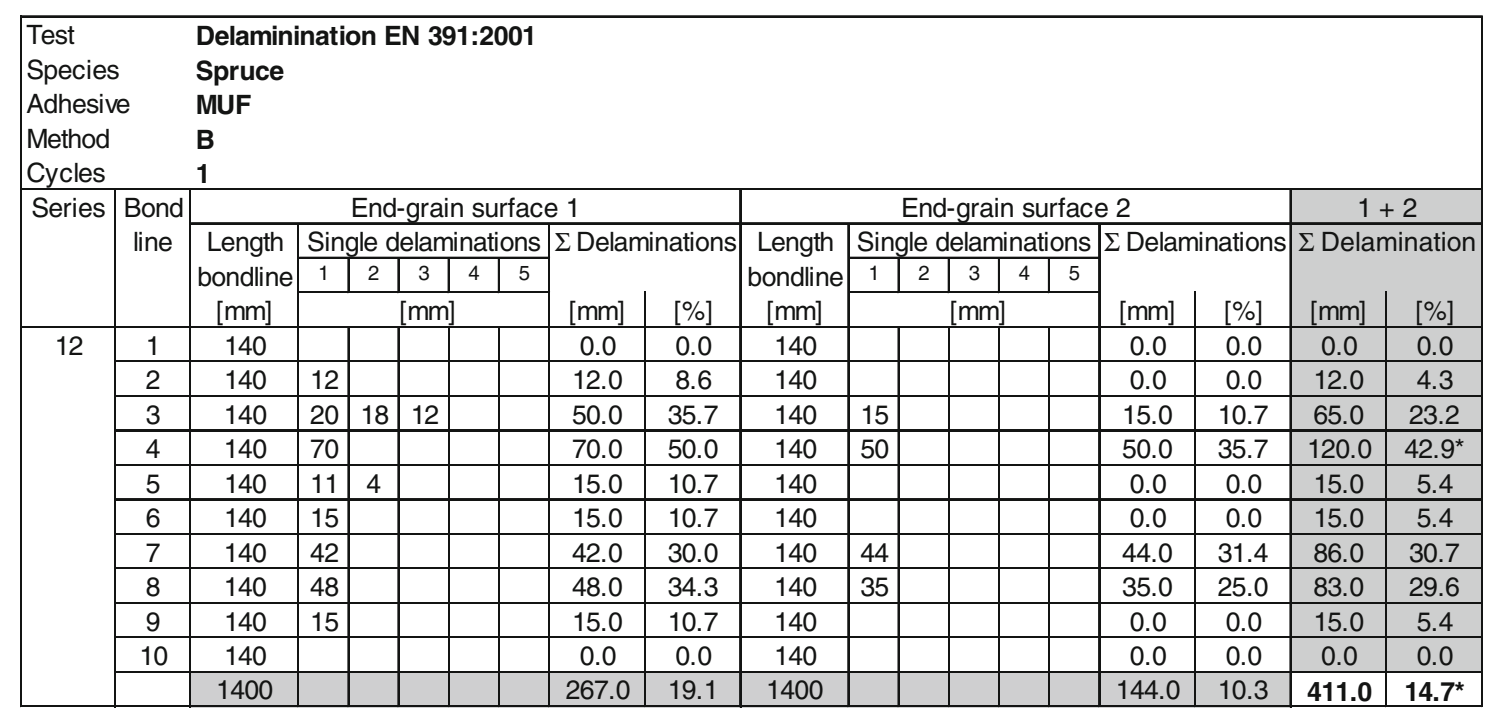

Fig. 1 Example of delamination test protocol (Series 12, Species: Norway spruce, Type of adhesive: MUF, Method B). Values with an asterisk do not reach the requested benchmark values (see Table 2)

Fig. 2 Example of block shear test protocol (Series 11.1 at $20{ }^{\circ} \mathrm{C} / 65 \%$ RH, Species: Norway spruce, Type of adhesive: PRF). Values with an requested benchmark values (see Table 3) asterisk do not reach the

\begin{tabular}{|c|c|c|c|c|c|c|c|}
\hline \multirow{4}{*}{\multicolumn{2}{|c|}{$\begin{array}{l}\text { Test } \\
\text { Species } \\
\text { Adhesive } \\
\text { Conditioning }\end{array}$}} & \multicolumn{6}{|c|}{ Block shear test EN 392:1995 } \\
\hline & & \multicolumn{6}{|c|}{ Spruce } \\
\hline & & \multicolumn{6}{|l|}{ PRF } \\
\hline & & \multicolumn{6}{|c|}{$20^{\circ} \mathrm{C} / 65 \% \mathrm{RH}$} \\
\hline \multirow[t]{3}{*}{ Series } & \multirow{3}{*}{$\begin{array}{l}\text { Bond } \\
\text { line }\end{array}$} & \multicolumn{2}{|c|}{ Bar 1} & \multicolumn{2}{|c|}{ Bar 2} & \multicolumn{2}{|c|}{ Mean of bars 1 and 2} \\
\hline & & $f_{v}$ & WFP & $f_{v}$ & WFP & $f_{v}$ & WFP \\
\hline & & {$\left[\mathrm{N} / \mathrm{mm}^{2}\right]$} & {$[\%]$} & {$\left[\mathrm{N} / \mathrm{mm}^{2}\right]$} & {$[\%]$} & {$\left[\mathrm{N} / \mathrm{mm}^{2}\right]$} & {$[\%]$} \\
\hline \multirow[t]{10}{*}{11.1} & 1 & 9.1 & 85 & $6.5^{*}$ & $55^{*}$ & 7.8 & 70 \\
\hline & 2 & $5.5^{*}$ & $85^{*}$ & 8.7 & 90 & 7.1 & 88 \\
\hline & 3 & 8.5 & 70 & 10.3 & 90 & 9.4 & 80 \\
\hline & 4 & 10.0 & 95 & 11.2 & 100 & 10.6 & 98 \\
\hline & 5 & 7.2 & 65 & 7.0 & 80 & 7.1 & 73 \\
\hline & 6 & 9.5 & 75 & 10.4 & 95 & 9.9 & 85 \\
\hline & 7 & 9.9 & 85 & 9.7 & 70 & 9.8 & 78 \\
\hline & 8 & 11.1 & 80 & 10.1 & 100 & 10.6 & 90 \\
\hline & 9 & 11.5 & 75 & 10.9 & 80 & 11.2 & 78 \\
\hline & 10 & 9.0 & 90 & 9.9 & 80 & 9.5 & 85 \\
\hline \multicolumn{2}{|l|}{ Mean } & 9.1 & 80.5 & 9.5 & 84 & 9.3 & 82 \\
\hline \multicolumn{2}{|c|}{ Standard deviation } & 1.76 & 9.3 & 1.59 & 14.1 & 1.47 & 8 \\
\hline \multicolumn{2}{|c|}{ Coeff. of variation } & $19 \%$ & $12 \%$ & $17 \%$ & $17 \%$ & $16 \%$ & $10 \%$ \\
\hline \multicolumn{2}{|c|}{ Minimum } & 5.5 & 65 & 6.5 & 55 & 7.1 & 70 \\
\hline \multicolumn{2}{|l|}{ Maximum } & 11.5 & 95 & 11.2 & 100 & 11.2 & 98 \\
\hline \multicolumn{2}{|l|}{$\mathrm{n}_{\text {fail }}$} & \multicolumn{2}{|c|}{1} & \multicolumn{2}{|c|}{1} & \multicolumn{2}{|c|}{-} \\
\hline \multicolumn{2}{|l|}{ Pass / Fail } & \multicolumn{2}{|c|}{ Fail } & \multicolumn{2}{|c|}{ Fail } & \multicolumn{2}{|c|}{ Pass } \\
\hline
\end{tabular}

line value' for direct comparison with delamination, which includes the full width of the glulam cross-section.

be compared to the variability of WFP.

- To combine the information of different test conditions, the results of delamination methods $\mathrm{A}$ and $\mathrm{B}$ were averaged. Average values were also calculated over the pre-conditioning treatments $1-3$ in the block shear tests.

- To allow a correct comparison over all delamination test series, only the results of the initial cycles were used (only few test series required extra cycles).

All three parameters $D I B, S F V$ and $S W F$ were first calculated for each glue line and in a second step averaged for each test series. In the test series with two parallel block shear test bars, the values were first averaged into one 'glue

\section{Results and discussion}

Selected examples of the raw data from the delamination and the shear tests are shown in Figs. 1 and 2, respectively. "Pass/Fail" evaluation of the delamination tests was done directly based on these data tables, while for the block shear tests it was assisted by two-dimensional graphs as presented in Fig. 3. Strictly speaking, the benchmark values for the block shear tests according to EN 386 are valid 
Fig. 3 Shear strengths and wood failure percentages of individual glue lines of series 1 after pre-conditioning at $20{ }^{\circ} \mathrm{C} /$ $65 \% \mathrm{RH}, 20{ }^{\circ} \mathrm{C} / 85 \% \mathrm{RH}$ and stress conditioning. The EN 386 limit according to Table 3 is marked with a thick solid line
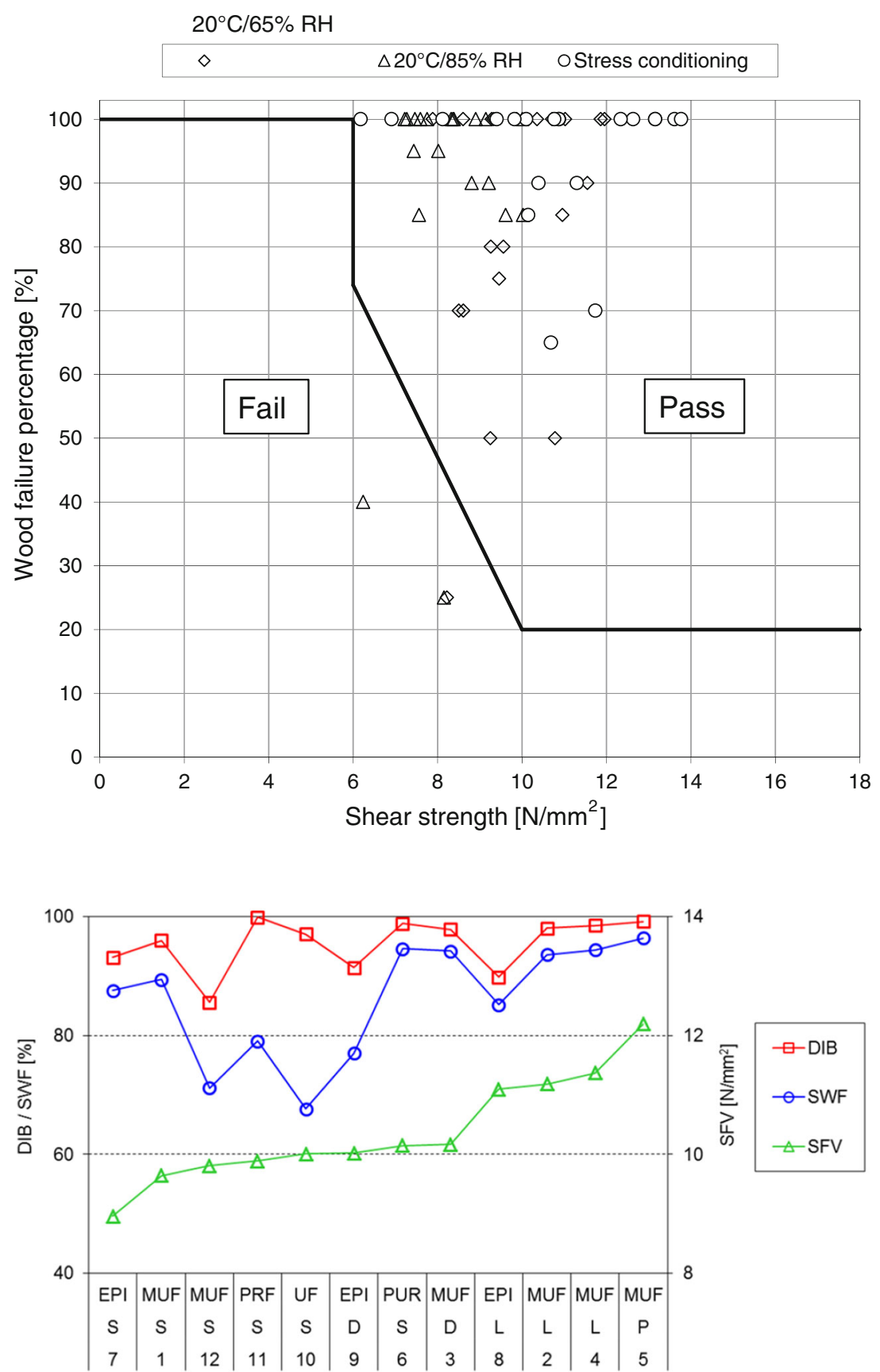

Fig. 4 Overview of mean test results described by the three measures of glue line integrity DIB (Intact glue lines after delamination), SWF (Wood failure percentage) and SFV (Shear strength). The abbreviations below the $x$-axis indicate type of adhesive, wood species and test series number (see Table 2). The test series are ranked according to the value of the parameter SFV $f_{v, a}$ from 8.3 to $13.6 \mathrm{~N} / \mathrm{mm}^{2}$ and wood failure percentage WFP from 58.3 to $98.2 \%$. Accordingly, the range of the individual glue line values in the shear tests was larger (shear strength $f_{v, a}$ from 4.6 to $16.1 \mathrm{~N} / \mathrm{mm}^{2}$, wood failure percentage WFP from 20 to $100 \%$ ).

Wood species, type of adhesive and the production quality will certainly influence the test results and their relationship. However, the graphical representation of the aggregated parameters $D I B, S F V$ and $S W F$ in Fig. 4 did not reveal any clear pattern in terms of wood species, 
Table 6 Comparison of test methods in terms of "Pass"/"Fail" outcomes

\begin{tabular}{|c|c|c|c|c|c|c|c|c|c|c|}
\hline \multirow[t]{4}{*}{ Series } & \multirow[t]{4}{*}{ Wood species } & \multirow[t]{4}{*}{ Type of adhesive } & \multirow{2}{*}{\multicolumn{2}{|c|}{$\frac{\text { Delamination test }}{\text { Method }}$}} & \multicolumn{6}{|c|}{ Block shear test } \\
\hline & & & & & \multicolumn{6}{|c|}{ After pre-conditioning at } \\
\hline & & & \multirow[t]{2}{*}{ A } & \multirow[t]{2}{*}{$\mathrm{B}$} & \multicolumn{2}{|c|}{ 1: $20^{\circ} \mathrm{C} / 65 \% \mathrm{RH}$} & \multicolumn{2}{|c|}{ 2: $20^{\circ} \mathrm{C} / 85 \% \mathrm{RH}$} & \multicolumn{2}{|c|}{ 3: stress climate } \\
\hline & & & & & $A V^{b}$ & $\mathrm{IV}^{\mathrm{b}}$ & $A V^{\mathrm{b}}$ & $\mathrm{IV}^{\mathrm{b}}$ & $A V^{b}$ & $\mathrm{IV}^{\mathrm{b}}$ \\
\hline 1 & $\mathrm{~S}$ & MUF & Pass & Pass & Pass & Fail & Pass & Fail & Pass & Pass \\
\hline 2 & $\mathrm{~L}$ & MUF & Pass & Pass & Pass & Pass & Pass & Pass & Pass & Pass \\
\hline 3 & $\mathrm{D}$ & MUF & Pass & Pass & Pass & Pass & Pass & Pass & Pass & Pass \\
\hline 4 & $\mathrm{~L}$ & MUF & Pass & Pass & Pass & Pass & Pass & Pass & Pass & Pass \\
\hline 5 & $\mathrm{P}$ & MUF & Pass & Pass & Pass & Pass & Pass & Pass & Pass & Pass \\
\hline 6 & $\mathrm{~S}$ & PUR & Pass & Pass & Pass & Pass & Pass & Pass & Pass & Pass \\
\hline 7 & $\mathrm{~S}$ & EPI & Fail & Fail & Pass & Pass & Pass & Pass & Pass & Pass \\
\hline 8 & $\mathrm{~L}$ & EPI & Fail & Fail & Pass & Fail & Pass & Fail & Pass & Pass \\
\hline 9 & $\mathrm{D}$ & EPI & Fail & Fail & Pass & Pass & Pass & Fail & Pass & Pass \\
\hline 10 & $\mathrm{~S}$ & UF & Pass & Pass & Pass & Fail & Pass & Fail & Pass & Pass \\
\hline 11 & $\mathrm{~S}$ & PRF & Pass & Pass & Pass & Fail & Pass & Pass & Pass & Pass \\
\hline 12 & $\mathrm{~S}$ & MUF & Fail & Fail & Fail & Fail & Pass & Fail & Pass & Pass \\
\hline
\end{tabular}

${ }^{a}$ Vacuum- and pressure-soaking in water according to EN 391 method B, followed by drying at $20^{\circ} \mathrm{C} / 35 \% \mathrm{RH}$

b Average (AV) and individual values (IV) of all tested glue lines

adhesives or specific combinations of the two. The test data also did not show any peculiarity in terms of origin of the test specimens. That is why in the further analysis the parameter "producer" was neglected. Because of the nonsystematic sample plan some adhesives were available only with single producers and thus no detailed analysis was possible in this regard. However, since the study aimed at comparing the results of different test methods and not the performance of individual producers and adhesives, this was not regarded as limitation.

The more or less parallel course of $D I B$ and $S W F$ (with exception of test series 10) suggested some relationship between the two parameters, while $S F V$ clearly showed a different pattern. As expected due to the higher wood density, $S F V$ recorded with the European larch (L) and Maritime pine $(\mathrm{P})$ series was higher than with Douglas fir (D) and Norway spruce (S).

\subsection{Agreement of both test methods in terms of "Pass" or "Fail" outcomes}

Based on the overall evaluation of the test results shown in Table 5, the "Pass/Fail" outcomes of the different tests are compiled in Table 6. The delamination tests led to four 'Fail' results, with a perfect agreement of methods A and B. These four test series failed to meet the requirements regarding total delamination $\left(D_{\mathrm{tot}}\right)$, and two of them additionally did not meet the requirements regarding the maximum delamination of single glue lines $\left(D_{\max }\right)$. The adopted lower limit of $30 \%$ in EN 14080 (European
Committee for Standardization CEN 2013) would not change these results.

The block shear tests resulted in between zero and five 'Fail' results with only a partial agreement. The "Pass/ Fail" decision based on individual glue line values clearly was the more restrictive requirement than the average value of the whole glulam cross-sections and was determining the test outcome. Subjecting the test specimens to stress climate prior to block shear testing obviously did not increase the test severity and did not help in detecting weaker glue lines with increased accuracy or in reaching a better agreement between delamination tests and block shear tests.

The agreement of the "Pass/Fail" outcomes was further analysed by a cross-tabulation of matching and contradicting results between delamination and shear tests (Table 7). Agreement of the "Pass/Fail" outcomes was between 58 and $75 \%$ of the 12 test series, which on the other hand means contradicting results in between three and five cases. However, as an indicator for statistical relevance a McNemar's test taking into account the matched pairs situation with dichotomous "Pass/Fail" responses, did not indicate any significant deviation from the expected marginal proportions of the contradicting results. Thus, despite some deviating test outcomes, no systematic disagreement between delamination and block shear tests was detected. The best agreement with the delamination test results was observed for the individual values of the block shear test after conditioning at $20{ }^{\circ} \mathrm{C} /$ $85 \% \mathrm{RH}$. 
Table 7 Cross tabulation of "Pass/Fail" outcomes in delamination and block shear tests

\begin{tabular}{|c|c|c|c|c|c|c|c|c|c|c|c|c|c|}
\hline & & \multicolumn{12}{|c|}{ Block shear test } \\
\hline & & \multicolumn{12}{|c|}{ After pre-conditioning at } \\
\hline & & \multicolumn{4}{|c|}{$20{ }^{\circ} \mathrm{C} / 65 \% \mathrm{RH}$} & \multicolumn{4}{|c|}{$20^{\circ} \mathrm{C} / 85 \% \mathrm{RH}$} & \multicolumn{4}{|c|}{ Stress conditioning $^{\mathrm{a}}$} \\
\hline & & \multicolumn{2}{|l|}{$\mathrm{AV}^{\mathrm{b}}$} & \multicolumn{2}{|l|}{$\mathrm{IV}^{\mathrm{b}}$} & \multicolumn{2}{|l|}{$A V^{b}$} & \multicolumn{2}{|l|}{$\mathrm{IV}^{\mathrm{b}}$} & \multicolumn{2}{|l|}{$A V^{b}$} & \multicolumn{2}{|l|}{$\mathrm{IV}^{\mathrm{b}}$} \\
\hline & & Pass & Fail & Pass & Fail & Pass & Fail & Pass & Fail & Pass & Fail & Pass & Fail \\
\hline \multirow[t]{4}{*}{ Delamination test } & Pass & 8 & 0 & 5 & 3 & 8 & 0 & 6 & 2 & 8 & 0 & 8 & 0 \\
\hline & & $67 \%$ & $0 \%$ & $41 \%$ & $25 \%$ & $67 \%$ & $0 \%$ & $50 \%$ & $17 \%$ & $67 \%$ & $0 \%$ & $67 \%$ & $0 \%$ \\
\hline & Fail & 3 & 1 & 2 & 2 & 4 & 0 & 1 & 3 & 4 & 0 & 4 & 0 \\
\hline & & $25 \%$ & $8 \%$ & $17 \%$ & $17 \%$ & $33 \%$ & $0 \%$ & $8 \%$ & $25 \%$ & $33 \%$ & $0 \%$ & $33 \%$ & $0 \%$ \\
\hline \multicolumn{2}{|c|}{ Agreement Pass/Fail ${ }^{\mathrm{c}}$} & \multicolumn{2}{|c|}{$75 \%$} & \multicolumn{2}{|c|}{$58 \%$} & \multicolumn{2}{|c|}{$67 \%$} & \multicolumn{2}{|c|}{$75 \%$} & \multicolumn{2}{|c|}{$67 \%$} & \multicolumn{2}{|c|}{$67 \%$} \\
\hline
\end{tabular}

\subsection{Correlation between delamination and shear test results}

In Figs. 5 and 6 the relationship between the numerical results of the delamination and the shear tests is presented in bivariate graphs of the 'aggregate' measures of glue line integrity $D I B$ versus $S F V$ and $S W F$, based on individual glue line values and on test series averages, respectively.

The individual glue line values (Fig. 5) did not reveal distinct correlations. A good example is the PRF adhesive, where some variability in the block shear test results ( $S F V$, $S W F$ ) has been seen, but virtually none in the delamination results $(D I B)$. Such data structures rule out any significant correlations from the beginning.

Based on test series averages, a weak correlation was present between $D I B$ and $S W F$, while no clear relationships was visible between $D I B$ and $S F V$ (Fig. 6). But despite the limited correlation, some interesting patterns could be detected. Generally, variability increased with decreasing property values. $S F V$ clearly depends on wood species (wood density), which is shown in the higher $S F V$ values for the European larch and Maritime pine series (Fig. 6, top right). On the other hand, $S W F$ and $D I B$ appear to be more grouped by type of adhesive (Fig. 6, bottom left). The observation that the three measures of glue line integrity are influenced by different factors and thus express different material properties, may be another reason for limited correlation. This may also explain why very little specific information on correlations is found in the literature.

\subsection{Sensitivity of the test methods}

A possible selection criterion for a specific test method may be its sensitivity to changing material characteristics.
As a measure for test sensitivity, the variability of results between the different test units could be used, provided that the variability is caused by the investigated experimental factors and not by inherent variability of the test method.

In Fig. 7, the variability of the three 'aggregate' measures of glue line integrity $D I B, S F V$ and $S W F$ between the individual glue lines in the 12 test series is compared using the coefficient of variation. Variability between the individual glue lines in the test series varied in a wide range between 0.3 and $25.9 \%$. Variability between the test pieces appeared to be more constant for $S F V$ than for $D I B$ and $S W F$, which on the other hand showed a good agreement concerning high or low variability within test pieces.

This approach is extended in Fig. 8, which compares the variability between individual glue lines (average value over 12 test series) and the variability between the average property values of the 12 test series. Both aspects closely agreed in an increasing variability of the three measures of glue line integrity from $D I B$ over $S F V$ to $S W F$. Being aware that the variability of all three parameters may be influenced by both the precision of the assessments (measurement, visual rating) and the 'real' variation of properties, it is still regarded as a general indication of the ability to discriminate between different bonding qualities. Based on these results, test sensitivity appeared to be higher for $S W F$ than for $D I B$.

\subsection{Detection of weak glue lines}

A final aspect of tests of glue line integrity is their ability to detect particularly 'weak' glue lines. This was studied by comparing the performance of individual glue lines according to the three measures of glue line integrity $D I B$, $S F V$ and $S W F$. Selected examples are shown in Fig. 9 for test series $1,8,9$ and 12 . 
Fig. 5 Relationship of individual glue line values between DIB (Intact glue lines after delamination) and SFV (Shear strength,) or SWF (Wood failure percentage) grouped according to type of adhesive (see Table 4) and wood species ( $\mathrm{S}=$ Norway spruce,

$\mathrm{L}=$ European larch,

$\mathrm{D}=$ Douglas fir, $\mathrm{P}=$ Maritime pine)

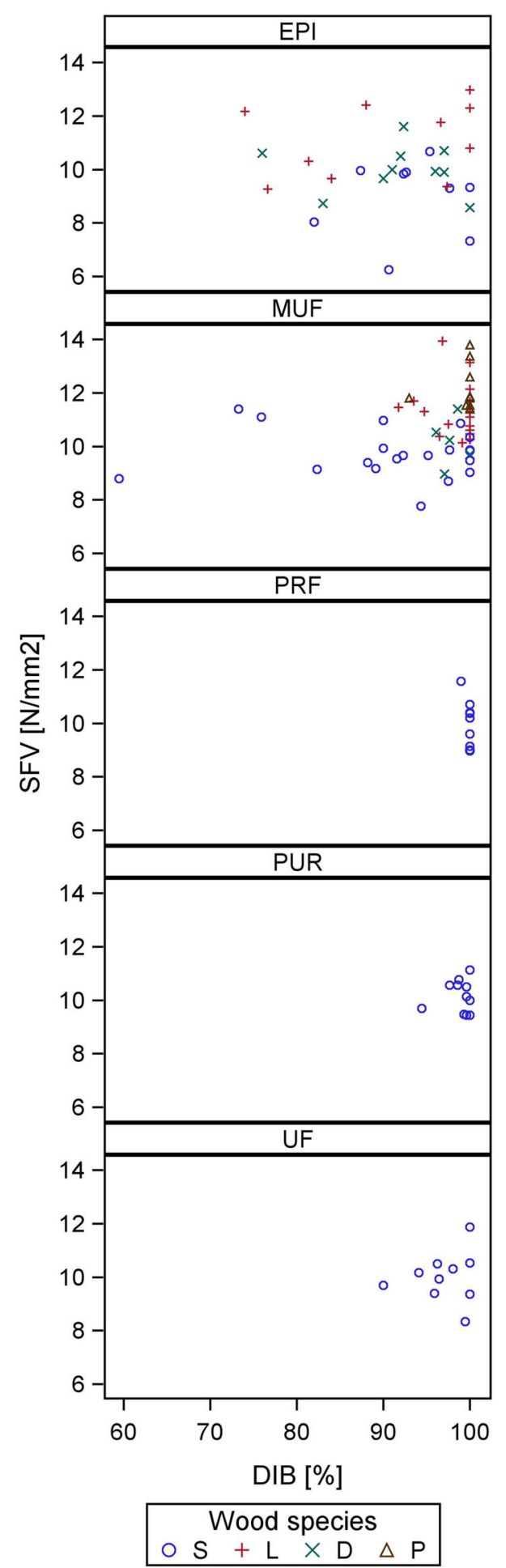

In test series 1, the three 'aggregate' measures of glue line integrity showed more or less uniform properties over all glue lines and no particularly weak glue lines were detected. In test series 8 , glue lines $1-5$ appeared to be clearly weaker than glue lines 6-10. However, again there was no agreement between the three measures regarding

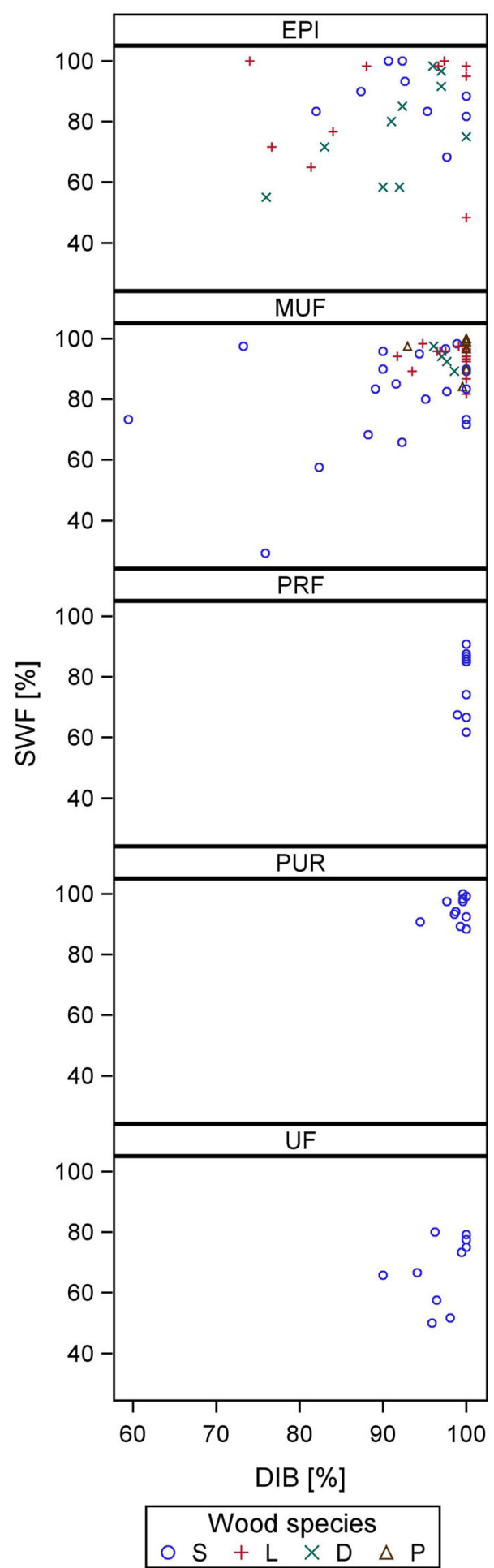

particularly weak individual glue lines. Glue line 6 in test series 9 is a rather rare example where all three parameters pointed to the same weak glue line. And finally in test series 12 , the parameters $D I B$ and $S W F$ showed a large variability, while $S F V$ again was relatively stable. Glue lines 3, 4 and 7 with particularly low values for $D I B$ or 

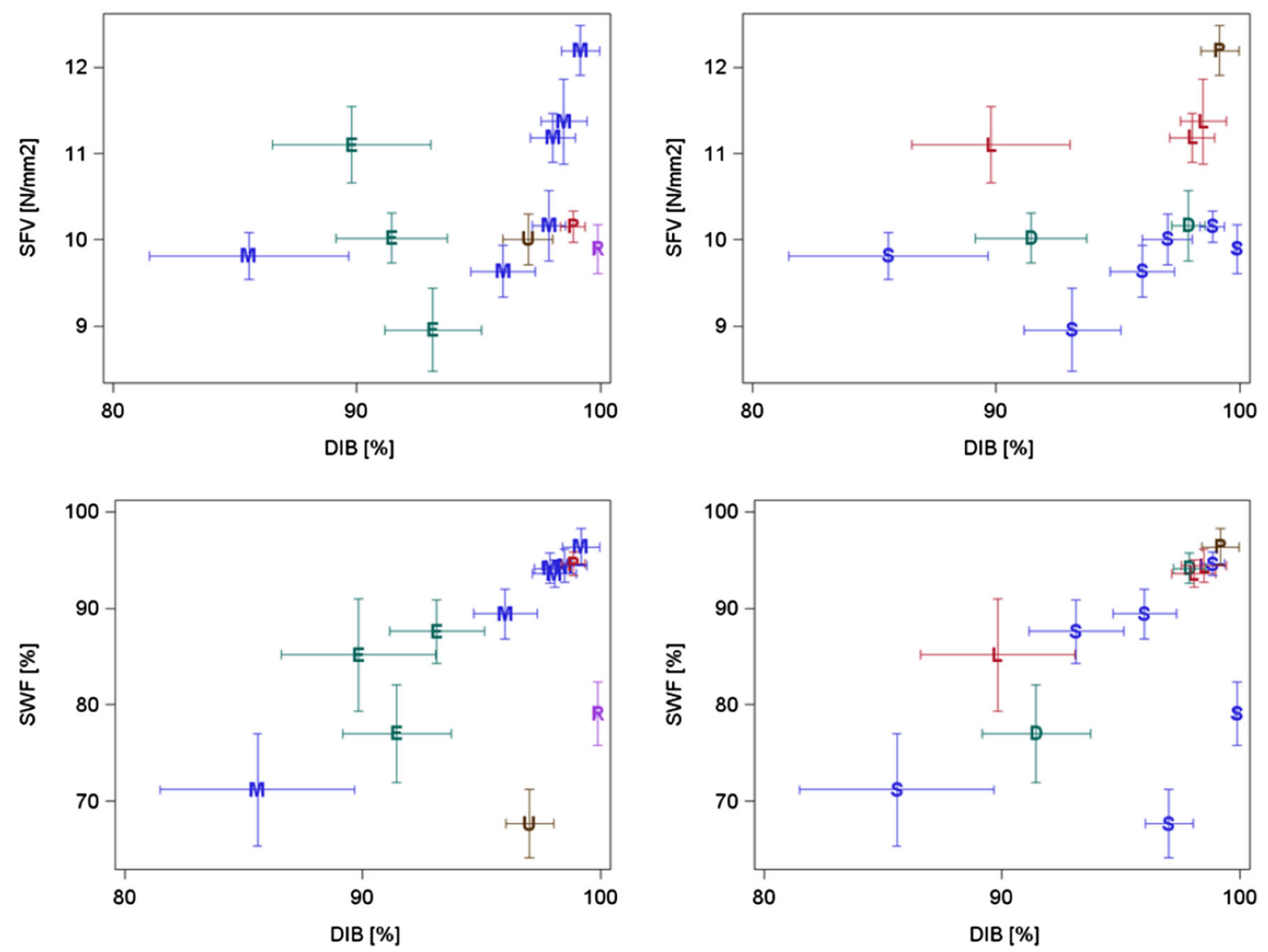

Fig. 6 Relationship of average values per test series between DIB (Intact glue lines after delamination) and SFV (Shear strength) or SWF (Wood failure percentage). Left and right hand graphs show the same data, but grouped according to type of adhesive (left column) and wood species (right column), respectively. The error bars

show \pm 1 standard error of the mean. Type of adhesive: $\mathrm{E}=\mathrm{EPI}$, $\mathrm{M}=\mathrm{MUF}, \quad \mathrm{P}=\mathrm{PUR}, \quad \mathrm{U}=\mathrm{UF}, \mathrm{R}=\mathrm{PRF}$. Wood species: $\mathrm{D}=$ Douglas fir, $\mathrm{L}=$ European larch, $\mathrm{P}=$ Maritime pine, $\mathrm{S}=$ Norway spruce

Fig. 7 Variability between individual glue lines in the 12 test series of the three measures of glue line integrity DIB (Intact glue lines after delamination), SFV (Shear strength) and SWF (Wood failure percentage)

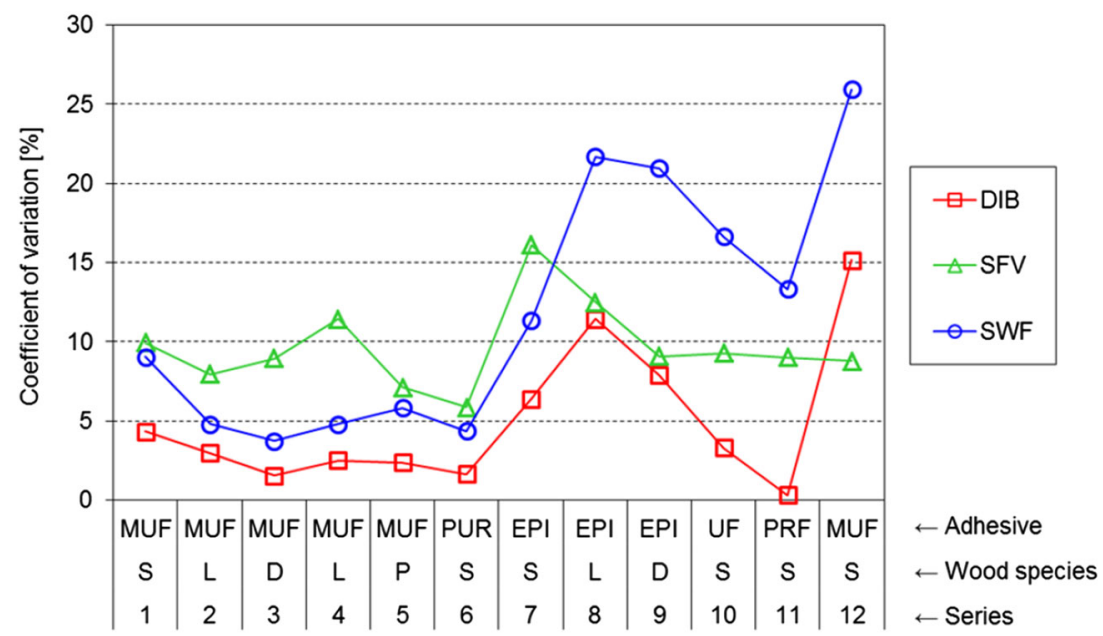

SWF did not show suspicious results in the other two measures of glue line integrity.

A possible explanation for the limited agreement of the three measures of glue line integrity regarding weak glue lines may be that there were no really weak glue lines. In fact, samples from high quality glulam were tested, where one does not expect weak glue lines. 


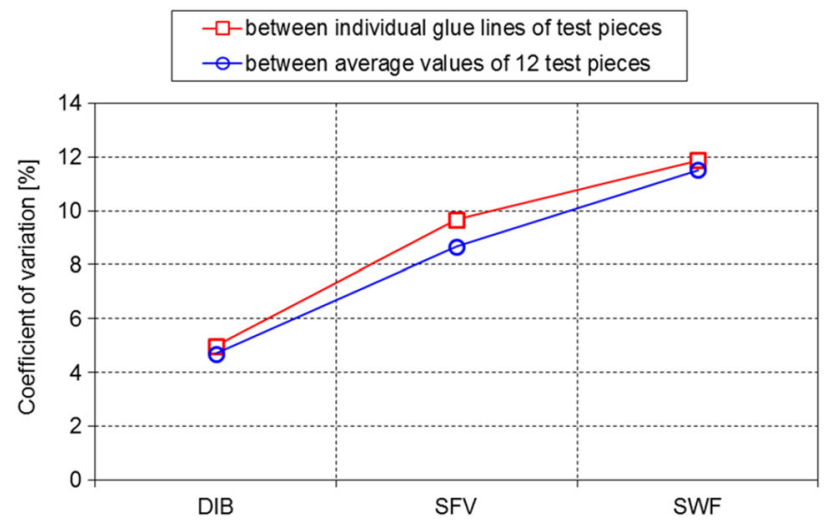

Fig. 8 Variability between individual glue lines (average value over 12 test series) and between average values of test series of the three measures of glue line integrity DIB (Intact glue lines after delamination), SFV (Shear strength) and SWF (Wood failure percentage)

\section{Conclusion}

The comparison of delamination and block shear test results from 12 series of structural softwood glulam including several wood species (Norway spruce, European larch, Douglas fir and Maritime pine) and different types of
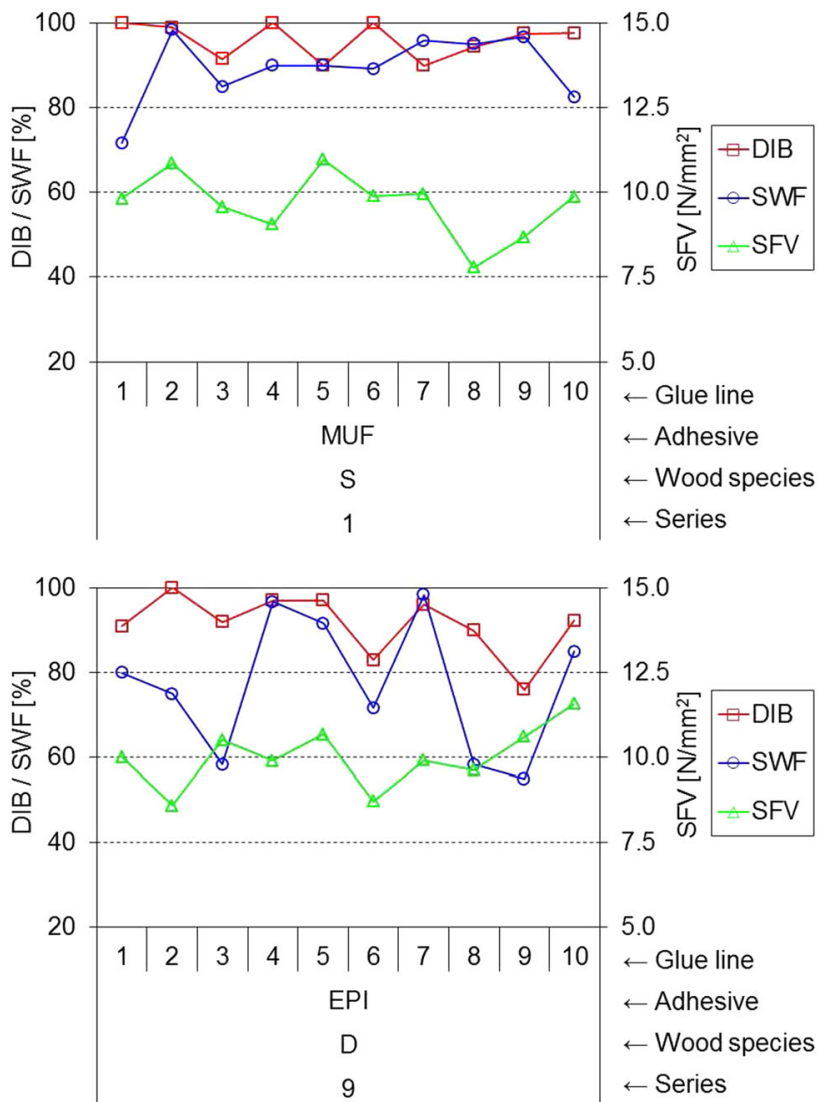

adhesives (MUF, PUR, EPI, UF, PRF) led to the following conclusions:

- Delamination testing according to EN 391 procedure B and according to the more severe and time-consuming procedure A did not reveal different results. Hence in FPC of softwood glulam produced from lamellas of the species Norway spruce, European larch, Douglas fir and Maritime pine it is sufficient to use procedure B. $D_{\text {tot }}$ was the more restrictive requirement than $D_{\max }$.

- In block shear testing, "Pass/Fail" decision is determined by insufficient test results of individual glue lines rather than insufficient mean values over all glue lines. Subjecting the test specimens to stress climate prior to carrying out the block shear tests did not improve the accuracy in detecting weak glue lines nor the agreement with results from delamination testing.

- The agreement of both delamination and block shear tests in assigning "Pass" or "Fail" to a single glue line in general is quite high. In $67-75 \%$ of the cases there was agreement when the "Pass/Fail" decision in the block shear tests was taken based on mean values of glue lines of test pieces. In the case of starting from
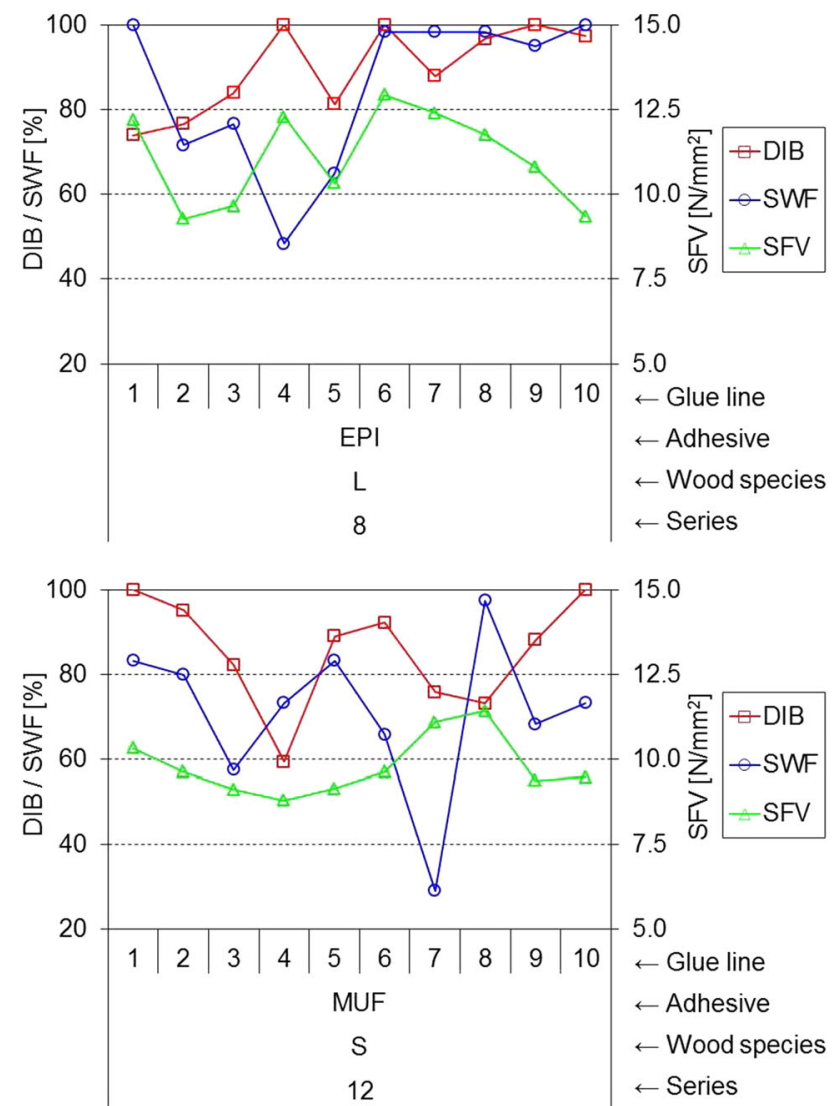

Fig. 9 Comparison of the performance of individual glue lines regarding the three measures of glue line integrity DIB (Intact glue lines after delamination), SFV (Shear strength) and SWF (Wood failure percentage) for selected test series 
individual glue line values the agreement was slightly lower $(58-75 \%)$.

- There is no strong correlation between test results from delamination and block shear tests (neither for the parameter shear strength nor for the wood failure percentage). On the mean level a weak correlation between the delamination test results and the wood failure percentage derived in block shear tests could be observed.

- Based on a comparison of the variability of the test results, test sensitivity regarding changing material properties appeared to increase from DIB (Parameter to describe the percentage of intact glue lines after the delamination test) over $S F V$ (Shear strength) to $S W F$ (Wood failure percentage after the block shear test). However, it has to be taken into account that the variability of the three parameters is composed of both the precision of the assessments and the 'real' variation of the properties.

- No general agreement in detecting weak glue lines was found between the three measures of glue line integrity $D I B, S F V$ and $S W F$.

Overall it was concluded, that the outcomes of delamination and block shear tests generally agree, but will not necessarily lead to the same test results in any case. Therefore, for FPC the choice of their application should be defined more specifically.

Acknowledgments This study was supported by the Swiss Federal Office for the Environment FOEN (Fonds zur Förderung der Waldund Holzforschung, Project number 2009.16). Five members of the Swiss Glulam Association SFH (www.glulam.ch) supplied the test material. The assistance of the Empa technicians Daniel Heer and Michael Strässle taking care of preparation of tests specimens and performing shear tests, respectively, is gratefully acknowledged.

\section{References}

Aicher S, Reinhardt H-W (2007) Delamination properties and shear strength of glued beech wood laminations with red heartwood. Holz Roh-Werkst 65(2):125-136 (in German)
American Society for Testing and Materials ASTM (1959) ASTM D 1101-59: integrity of glue joints in structural laminated wood products for exterior use. American Society for Testing and Materials ASTM International West Conshohocken, Pennsylvania

American Society for Testing and Materials ASTM (2003) ASTM D 905-03: Standard test method for strength properties of adhesive bonds in shear by compression loading. American Society for Testing and Materials ASTM International West Conshohocken, Pennsylvania

Bodig J, Jayne BA (1993) Mechanics of wood and wood composites. Krieger Publishing Company, Malabar

Coker EG, Coleman GP (1935) Photo-elastic investigations of sheartests of timber. Institution of Civil Engineers, London

European Committee for Standardization CEN (1995) EN 392: Glued laminated timber-Shear test of glue lines. CEN, Brussels

European Committee for Standardization CEN (2001a) EN 386: Glued laminated timber-Performance requirements and minimum production requirements. CEN, Brussels

European Committee for Standardization CEN (2001b) EN 391: Glued laminated timber-Delamination test of glue lines. CEN, Brussels

European Committee for Standardization CEN (2004) EN 1995-1-1: Eurocode 5: Design of timber structures-Part 1-1: GeneralCommon rules and rules for buildings. CEN, Bruxelles

European Committee for Standardization CEN (2013) EN 14080: Timber structures-Glued laminated timber and glued solid timber-Requirements. CEN, Bruxelles

Ohnesorge D, Richter K, Becker G (2010) Influence of wood properties and bonding parameters on bond durability of European Beech (Fagus sylvatica L.) glulams. Ann For Sci 67(6):601

Radcliffe BM, Suddarth SK (1955) The notched beam shear test for wood. For Prod J 5(2):131-135

Raknes E (1983) Durability of structural wood adhesives after 15 years aging. Ind Eng Chem Prod Res Dev 22(4):662-664

Raknes E (1997) Durability of structural wood adhesives after 30 years aging. Holz Roh-Werkst 55(2):83-90

Schmidt M, Glos P, Wegener G (2010) Gluing of European beech wood for load bearing timber structures. Eur J Wood Prod 68(1):43-57 (in German)

Steiger R, Gehri E, Richter K (2010) Quality control of glulam: shear testing of bondlines. Eur J Wood Prod 68(3):243-256

Zeppenfeld G, Grunwald D (2005) Klebstoffe in der Holz- und Möbelindustrie. DRW-Verlag, Leinfelden-Echterdingen 